DOI: $10.21802 / \mathrm{artm} .2021 .2 .18 .66$

UDC 616.314-07+616.314-085+616.314.25/.26

\title{
FEATURES OF DIAGNOSIS AND TREATMENT OF PATIENTS WITH REDUCED BITE HEIGHT
}

\author{
A.B. Kostyshyn \\ Ivano-Frankivsk National Medical University, Department of Orthopedic Dentistry, \\ Ivano-Frankivsk, Ukraine, \\ ORCID ID: 0000-0001-5500-0874, e-mail: kostushunzorjana1907@gmail.com
}

Abstract. Aesthetic and hygienic requirements of patients with reduced bite height necessitate the use of modern orthopedic constructions. The main cause of this disease is pathological abrasion of the hard tissues of the teeth, the prevalence of which ranges from 4 to $57 \%$ at a young age, reaches $91 \%$ in the elderly and is accompanied by both morphological and functional disorders of the dental-maxillary system.

The aim. Research the features of the diagnosis of dental status in patients with reduced bite height and timing of their treatment.

Materials and methods. Determine the degree of reduction in the height of the bite in persons with pathological abrasion of the hard tissues of the teeth of varying severity compared with the norm and features of its recovery.

Results. In order to prepare for orthopedic treatment, we determined the height of the bite in 123 patients. Accordingly, they were divided into three groups. Group 1 consisted of 32 patients with included dentition defects with reduced bite height up to $2 \mathrm{~mm}(\mathrm{n}=32)$, group 2 - examined with included dentition defects with reduced bite height 2 $4 \mathrm{~mm}(\mathrm{n}=31)$, group 3 are patients with included dentition defects with reduced bite height of 4-6 mm $(n=30)$. All persons of the main groups belonged to the second and third age groups according to the WHO, aged 35-55 years, who required orthopedic treatment with fixed constructions of dentures.

The control group $(\mathrm{n}=30)$ are young people who belonged to the 1 st WHO age group (age - 18-34 years) with intact dentition, without concomitant somatic and dental pathology, were examined in one visit.

In order to study the degree of dependence of bite height reduction between incisors, canines, premolars and molars, we studied 30 gypsum models of supergypsum of the upper and lower jaws without reduction of bite height and 93 - with varying degrees of pathological abrasion of tooth hard tissues of all examined people.

The models were fixed in a standard articulator in the central occlusion position. Using a caliper, we determined the size of the tooth crowns and compared it with standard sizes.

In this research, we found the dependence of the degree of reduction in the height of the bite in the area of molars - premolars - incisors and canines in the ratio 1: 1,25: 1,5.

We performed orthopedic treatment and subsequent clinical observation for each patient for 6 months, examining their condition after fixation of prostheses in 1 week and in 1, 3 and 6 months after orthopedic treatment.

Based on the diagnosis of bite height reduction, we provided practical recommendations on the terms of use of fixed pharmacy bridges prostheses according to the degree of bite height reduction in the examined people.

In the case of patients with a decrease in bite height by $3-4 \mathrm{~mm}$, permanent orthopedic treatment is possible in 90 days after fixation of temporary orthopedic constructions in the oral cavity, and in patients with a reduced bite height of more than $4 \mathrm{~mm}$ - in 180 days.

Conclusions. According to the results of the research, a high efficiency of determining the degree of reduction in bite height in preparing patients for permanent orthopedic treatment depending on the severity of the pathological process.

Keywords: bite height, tooth abrasion.

Introduction. All types of pathology of the masticatory system disrupt its function. The most common of these is a decrease in bite height, which occurs due to abrasion of the teeth.

Researches by anthropologists show that this problem is relevant worldwide and modern, because researches of the teeth of ancient people show the absence of signs of this pathological symptom complex. Dentists know that tooth abrasion is physiological and pathological.

In particular, the physiological abrasion of the teeth, which, although associated with a pathological condition - hypercementosis, however, is mutually com- pensatory. At the same time, pathological abrasion, which is the main manifestation of decreased bite height, has a polyetiological origin and requires detailed study.

Orthopedic dentistry clinic is often visited by patients with this pathology, in whom the time is prolonged and the rhythm of chewing is reduced, chewing efficiency deteriorates compared to the norm, and there are serious disorders of masticatory muscle coordination in general $[1,2]$.

In addition, periodontal diseases, which are associated with untreated reduction in bite height, have a complicated course and require long-term comprehensive treatment [3]. 
At orthopedic treatment of persons with such complications preliminary special preparation is necessary, and they aspire to receive optimum aesthetic results of stomatologic reception in the shortest possible time. Therefore, to ensure quality treatment of patients, namely, to increase the height of the bite, and in order to meet their requirements, the clinic is increasingly using temporary crowns and bridges [4,5].

Rationale for the research. Despite the development and implementation of modern means of prevention, there is a tendency to increase dental morbidity, which requires orthopedic intervention. This is especially true for patients with reduced bite height due to pathological abrasion of the hard tissues of the teeth. The prevalence of pathological abrasion of the hard tissues of the teeth ranges from 4 to $57 \%$ at a young age and reaches $91 \%$ in the elderly [6], accompanied by both morphological and functional disorders of the dental jaw system.

Decrease in bite height occurs when the vertical size decreases and the interocclusal distance increases, which decreases unevenly with the loss of each tooth and depends on the presence and location of the remaining teeth and the presence of removable orthopedic constructions in the patient's mouth, age, region of residence [7].

Factors that lead to the loss of bite height are changes in traditions and habits in society - accelerating the pace of life, stress, excessive consumption of sour drinks and foods, ignoring the standards of oral hygiene.

The significant role of acids in reducing the height of the bite, microbial factor, harmful working conditions has been experimentally proven. One of the leading factors in the occurrence of pathological abrasion of tooth enamel is genetic.

Among the functional changes in this pathology, especially in bruxism, are considered dysfunctional disorders of the temporomandibular joints, changes in the bioelectrical activity of the masticatory muscles and the microcirculatory tract of periodontal tissues of the teeth that maintain the height of the bite. At the same time, morphological changes are accompanied by functional disorders of the biodynamic balance of the masticatory muscles, often to the stage of decompensation [8].

Important is the dependence of the nature of abrasion of teeth and reduction of bite height on the type of pathological bite of the patient, diseases of the gastrointestinal tract, dysfunction of the masticatory muscle group with the occurrence of orofacial pain.

However, a debatable issue in the scientific literature is the problem of determining the degree of reduction in the height of the lower third of the face, which is manifested in persons with pathological abrasion of the teeth, so there is a need for its diagnosis.

There are a number of techniques for determining bite height. In particular, the authors propose a method for determining the optimal length of the crowns of the upper incisors and canines by multiplying the values of their mesiodistal diameters by the coefficients of gender determinism. A.A. Remizova proposed a mathematical formula for calculating the height of the bite, which is based on radiometry data. One of the most accurate and complex methods for determining bite height, a number of authors consider cephalometry of the facial skeleton.
R.O. Mirza offers a method for determining the occlusal height of the bite, which includes determining the parameters of the face, characterized in that with a caliper on the skin of the face mark the points: $\mathrm{N}$ - nazion. (the area of the largest indentation on the skin corresponding to the naso- frontal suture), Sn - subnasal (the area of the skin indentation corresponding to the transition of the upper lip into the skin septum of the nose), L is the point lying on the midline of the face on the border of the transition of the red border of the lower lip, in the absence of bite height violations, the distance $\mathrm{N}-\mathrm{X}$ is equal to the distance $2 \mathrm{~N}-\mathrm{Sn}$, with decreasing distance $\mathrm{N}$ $\mathrm{X}$ relative to distances $2 \mathrm{~N}-\mathrm{Sn}$ set decrease in bite height, with increase - increase in height.

R.V. Kozak [9] proposes a technique, which consists in making X-ray contrast marks with filling material within the blind fossa of the first permanent molars of the lower and upper jaws to determine the degree of reduction in bite height.

However, most forms of bite height reduction are local and can be treated passively. In particular, reducing it by $3 \mathrm{~mm}$ is an indication for a gradual increase in bite height.

From this we can conclude that the decrease in bite height is accompanied by a number of pathological conditions, where the leading role is played by the masticatory muscles [10]. Therefore, insufficient study of muscle condition when drawing up a plan of orthopedic treatment of patients with reduced bite height leads to complications that occur after permanent prosthetics and are characterized by chips of the facing material, pathological changes in the temporomandibular joint, masticatory muscles, circulatory disorders.

The problem of choosing the method and duration of treatment when reducing the height of the bite, taking into account the condition of the masticatory muscles remains relevant, because even with the loss of one tooth or poor restoration, there may be a slight dysfunction of chewing, and with increasing lost teeth changes the position of the jaws in space and the lower third of the face decreases, there is a violation of coordination of masticatory muscles [11].

However, the above techniques do not take into account the presence of included defects of the dentition when reducing the bite height and the need for orthopedic treatment to restore normal bite height.

As practice shows, for the choice of method and timing of treatment it is necessary to determine accurately the degree of reduction in bite height.

The aim of the research. Research the features of the diagnosis of dental status in patients with reduced bite height and timing of their treatment.

Materials and methods of research. We examined 93 patients with included defects of the dentition and reduced bite height. All patients of the main groups belonged to the second and third age groups according to the WHO, aged 35-55 years, who require orthopedic treatment with fixed constructions of dentures.

Subjective and objective research methods were used for diagnosis. Survey data were entered into a specially designed map. Particular attention in the examination map was paid to the main reason for the decrease in bite height, which was mixed pathological abrasion of the 
teeth, as well as the bite. Patients had a fixed orthognathic or direct bite, in the anamnesis there are no complaints of LTMJ and bruxism. Patients were admitted for treatment with a diagnosis of a Class III Kennedy dentition defect.

Patients were under our observation for 6 months, electromyographic parameters of their masticatory muscles were studied before orthopedic treatment, after fixation of prostheses after 1 week and after 1, 3, 6 months.

The control group consisted of 30 young people who belonged to the 1st WHO age group (age - 18-34 years) with intact dentition. They were examined in one visit.

Research results and their discussion. As a basis for determining the degree of reduction in the height of the bite, we chose the method of anthropometric determination of standard sizes of tooth crowns by S.V. Radlinsky [12, 13]. In it, the author gives the standard sizes of dental crowns in the mesio-distal, vestibulo-oral directions and the heights of dental crowns, which were measured on gypsum models with a caliper. They are described in table.1.

The degree of reduction in bite height is determined by indicators of reduction in bite height in the frontal area of the dentition. However, there are cases of

absence of antagonist teeth or teeth of the frontal area in general in the presence of them in the lateral department.

In order to study the degree of dependence of bite height reduction between incisors, canines, premolars and molars, we studied 30 gypsum models of upper and lower jaw superhypsum without occlusion reduction and 93 - with varying degrees of pathological abrasion of dental hard tissues.

The models were fixed in a standard articulator in the central occlusion position. Using a caliper, we determined the size of the tooth crowns and compared it with standard sizes.

In this research, we found the dependence of the degree of reduction in the height of the bite in the area of molars - premolars - incisors and canines in the ratio 1: 1,25: 1,5 .

Thus, even in the absence of a certain group of teeth in patients, it was possible to determine to which group of patients they belong. Based on the definition of bite height reduction, we formed three groups. Group 1 consisted of 32 patients with included dentition defects with reduced bite height up to $2 \mathrm{~mm}$, group 2 - 31 patients with included dentition defects with reduced bite height 2-4 mm, group 3 consisted of 30 patients with included dentition defects with reduced bite height 4-6 $\mathrm{mm}$.

Table 1

Standard sizes and height of tooth crowns (mm) according by S. Radlinsky

\begin{tabular}{|c|c|c|c|c|c|c|c|c|}
\hline & \multicolumn{8}{|c|}{ Upper teeth } \\
\hline Sizes of crowns & 1 & 2 & 3 & 4 & 5 & 6 & 7 & 8 \\
\hline Mesio-distal, mm & 8,5 & 6,5 & 7,5 & 7,0 & 7,0 & 10,5 & 9,5 & 8,5 \\
\hline Vestibulo-oral, $\mathrm{mm}$ & 7,0 & 6,0 & 8,0 & 9,0 & 9,0 & 11,0 & 11,0 & 10,0 \\
\hline Crown height, $\mathrm{mm}$ & 10,5 & 9,0 & 10,0 & 8,5 & 8,5 & 7,5 & 7,0 & 6,5 \\
\hline & \multicolumn{8}{|c|}{ Lower teeth } \\
\hline Mesio-distal, $\mathrm{mm}$ & 5,0 & 5,5 & 7,0 & 7,0 & 7,0 & 11,0 & 10,5 & 10,0 \\
\hline Vestibulo-oral, mm & 6,0 & 6,5 & 7,5 & 7,5 & 8,0 & 10,0 & 10,0 & 9,5 \\
\hline Crown height, $\mathrm{mm}$ & 9,5 & 9,5 & 11,0 & 8,5 & 8,0 & 7,5 & 7,0 & 7,0 \\
\hline
\end{tabular}

All patients in the main groups required orthopedic treatment of fixed constructions of dentures.

Persons in the control group $(n=30)$ are young people with intact dentition without a decrease in bite height, without concomitant somatic and dental pathology.

One of the methods of improving the quality of orthopedic treatment with fixed bridges with reduced bite height taking into account the condition of the masticatory muscles is the preparation of patients, namely: the use of temporary fixed constructions that provide a gradual increase in bite height, allow to normalize the masticatory muscle contribute to the restructuring of "usual" myostatic reflexes.

For this purpose, we have improved the method of manufacturing provizer plastic bridges using hot polymerization plastic "Sinma M + V" ("Stoma", Kharkiv, Ukraine). Our laboratory stage of modeling and polymerization of the prosthesis is excellent, where fiberglass beams and tapes are used as reinforcing elements.

The effectiveness of treatment to reduce the height of the bite in terms of preparation for orthopedic treatment, we determined the degree of adaptation of the masticatory muscles to temporary bridges using electromyographic examination.

We examined patients of the three main groups for 6 months and, accordingly, obtained the following results: due to the gradual increase in bite height with temporary plastic bridges prosthetic, a positive dynamics of results was achieved, which indicates the effectiveness of preparing the dental-maxillary system for permanent orthopedic treatment with fixed constructions.

Namely, in electromyographic examination in a state of relative physiological rest in 1 month after temporary treatment with orthopedic constructions, m.masseter and m.temporalis indexes in patients of group 1 were almost equal to those of the control group and were for the right m.masseter - $(31,60 \pm 0.73) \mu \mathrm{V}(\mathrm{p}>$ $0.05)$, for the left m.masseter - $(32.29 \pm 0.72) \mu \mathrm{V}(\mathrm{p}>$ $0.05)$, for the right m.temporalis $-(31.24 \pm 1.08) \mu \mathrm{V}(\mathrm{p}>$ $0.05)$, for the left m.temporalis - $(31.48 \pm 0.63) \mu \mathrm{V}$ (p> $0.05)$, similar results in patients of the second group were observed 6 months after treatment and were for the right m.masseter - $(32.36 \pm 0.76) \mu \mathrm{V}(\mathrm{p}<0.05)$, for the left m.masseter - $(34.22 \pm 0.58) \mu \mathrm{V}(\mathrm{p}>0.05)$, for the right m.temporalis - $(33.52 \pm 0,68) \mu \mathrm{V}(\mathrm{p}>0.05)$, for the left 
m.temporalis $-(33.97 \pm 0.49) \mu \mathrm{V}(\mathrm{p}>0.05)$. Also in this group there was the most active dynamics of restoring muscle tone, which is explained by the maximum compensatory capabilities and the ability to regenerate the dental-maxillary system while reducing occlusion by 3-4 $\mathrm{mm}$.

In patients of group 3 in the same period of time there was only an approximation of the indicators to similar control groups, indicating muscle atrophy due to both physiological changes in the body and the degree of reduction in bite height.

At the same time, in patients of all groups, normalization of data in comparison with the control group was observed not later than one month after orthopedic treatment.

When observing patients, it is necessary to note the effectiveness of clearly determining the reduction in bite height, the use of temporary constructions and the need for comparative characterization of each patient's data to determine the degree of readiness for permanent orthopedic treatment. Thus, in patients of group 1 pronounced positive dynamics was observed after 1 month. Proof of this is the stabilization of the process in 6 months.

In persons of group 2 there was a pronounced positive dynamics after 3 months, and after 6 months clearly close to the data of patients in the control group.

In the examined group 3 there was only an approximation of data to patients in the control group with a pronounced positive trend after 6 months.

In addition, our researches have shown that in patients of groups 1-2 in 6 months after temporary orthopedic treatment to raise the height of the bite, the functions of m.masseter and m.temporalis are completely restored.

During the same period, in the examined 3 groups, a positive tendency to normalization of the condition and function of the masticatory muscles and chewing is clearly observed due to the restoration of the bite height.

Conclusions. Our researches have shown that changes in the dental-maxillary system depend on the severity of the pathological process, in particular, on the reduction of bite height.

The key is the question of accurate determination of the intercellular height of the jaws. It determines the timing of the gradual increase in bite height and adaptation of the masticatory muscles to permanent prostheses after orthopedic treatment.

Our conducted research allows us to clearly diagnose and determine the degree of reduction in bite height due to pathological abrasion of teeth, as well as to recommend fixed temporary acrylic bridges as a reliable orthopedic construction to prepare the dental-maxillary system for permanent orthopedic treatment.

Accordingly, we have provided practical advice on the timing of the use of non-removable temporary bridges prostheses. In particular, in patients with a decrease in bite height by $2-4 \mathrm{~mm}$, permanent orthopedic treatment is possible after 90 days after fixation of temporary orthopedic construction in the oral cavity, and in patients with a reduced bite height of more than $4 \mathrm{~mm}$ after 180 days.
Prospects for further research. Confirm the effectiveness of the diagnosis of patients with reduced bite height, our recommended treatment is planned to further research the adaptation processes and restore the function of the dental-maxillary system due to the restoration of bite height.

\section{References:}

1. Bida OV, Struk VI. Zminy funktsionalnoho stanu zhuvalnykh myaziv u osib z patolohichnym styranniam zubiv riznoho stupenia tiazhkosti porivniano $\mathrm{z}$ normoiu. Suchasna stomatolohiia. 2018; (4):72-75.

2. Struk VI, Zabuha YuI. Osoblyvosti ortopedychnoho likuvannia patsiientiv $\mathrm{z}$ patolohichnym styranniam tverdykh tkanyn zubiv zi zberezhenniam yikh vitalnosti. Suchasna stomatolohiia. 2019; (1):88-90.

3. Nikolov VV, Korol DM, Zaporzhchenko IV, Korol MD. Stan zhuvalnoi efektyvnosti u patsiientiv, yakym provedena restraktsiia yasen do protezuvannia neznimnymy zubnymy protezamy. Visnyk problem medytsyny i biolohii. 2018; 2(144):369-372.

4. Kostyshyn AB. Features of manufacture of advanced provisional bridge-based prostheses. Art of Medicine. 2021; 1(17):33-37. DOI: 10.21802/artm. 2021.1.17.33

5. Kostyshyn AB, Rozhko MM, Pelekhan LI. Yakisni kharakterystyky form poverkhnevykh elektromiohram $\mathrm{u}$ patsiientiv iz znyzhenoiu vysotoiu prykusu. Halytskyi likarskyi visnyk. 2014; 21(4):35-39.

6. Bida VI, Struk VI, Zabuha YuI. Patolohichne styrannia zubiv ta yoho likuvannia. Chernivtsi: Bukrek; 2015. P.72.

7. Shcherbenko AO. Vyznachennia pidvyshchenoho styrannia zubiv u pidlitkiv: teoretychnyi ohliad ta analiz vyrishennia problemy. Svit medytsyny i biolohii. 2017; 2(60):194-198.

8. Bida VI, Bida OV, Struk VI, Sydorenko TH. Pokaznyky mikrotsyrkuliatsii tkanyn parodontu v osib $\mathrm{z}$ pa

tolohichnym styranniam tverdykh tkanyn zubiv riznoho stupenia tiazhkosti, uskladnenym bruksyzmom: Zbirnyk naukovykh prats spivrobitnykiv NMAPO im. P.L. Shupyka. Kyiv. 2015; 24(1):471-477.

9. Kozak RV. Metodyka opredelenyia mezhalveoliarnoi vusotu pry patolohycheskoi styraemosty zubov. Stomatolohycheskaia nauka y praktyka. 2014; 2(2):24-27.

10. Korol MD, Nidzelskyi MIa, Korol DM, Tkachenko IM, Pysarenko OA. Funktsionalna aktyvnist vlasne zhuvalnykh m'iaziv pry intaktnykh zubnykh riadakh, a takozh pry defektakh i deformatsiiakh zubnykh riadiv. Visnyk problem medytsyny i biolohii. 2017; 3,2(138):189-192.

11. Havaleshko VP. Osoblyvosti protezuvannia defektiv zubnykh riadiv $\mathrm{u}$ patsiientiv iz revmatoidnym artrytom. Visnyk problem medytsyny i biolohii. 2019; 1, 2(149):337-340.

12. Radlinskyi SV. Synkhromiohrafiia u systemnomu vidnovlenni okliuzii. Dentart. 2018; (2):35-57.

13. Radlinskyi SV. Vidnovlennia rozkolotykh zubiv. Dentart. 2020; (3):13-26. 


\section{УДК 616.314-07+616.314-085+616.314.25/.26 \\ ОСОБЛИВОСТІ ДІАГНОСТИКИ ТА ЛІКУВАННЯ ПАЦІЕНТІВ ЗІ ЗНИЖЕНОЮ ВИСОТОЮ ПРИКУСУ}

\section{А.Б. Костишин}

Івано-Франківський національний медичний університет, кафедра ортопедичної стоматологї,

м. Івано-Франківськ, Украӥна,

ORCID ID: 0000-0001-5500-0874,

e-mail: kostushunzorjana1907@gmail.com

Резюме. Естетичні вимоги пацієнтів зі зниженою висотою прикусу зумовлюють необхідність застосування сучасних ортопедичних конструкцій. Основною причиною даного захворювання $\epsilon$ патологічне стирання твердих тканин зубів, поширеність якого від 57 \% у молодих до $91 \%$ у старших людей і супроводжується порушеннями зубощелепної системи.

Мета. Дослідити особливості діагностики стоматологічного статусу в пацієнтів зі зниженою висотою прикусу та терміни їх лікування.

Матеріали i методи. Визначити рівень зниження висоти прикусу в осіб 3 патологічним стиранням твердих тканин зубів та особливості їі відновлення.

Результати. 3 метою підготовки до ортопедичного лікування нами було проведено визначення висоти прикусу в 123 пацієнтів. Групу 1 складали 32 особи 3 включеними дефектами зубних рядів із зниженою висотою прикусу до 2 мм, аналогічно 2 групу - 31 обстежуваний зі зниженою висотою прикусу 2-4 мм. Відповідно 3 група - це 30 пацієнтів зі зниженою висотою прикусу 4-6 мм. Всі обстежувані основних груп, віком 35-55 років, потребували ортопедичного лікування незнімними конструкціями зубних протезів.

Особи контрольної групи - це 30 молодих людей, вік - 18-34 роки, з інтактними зубними рядами, без супутньої соматичної та стоматологічної патології.

Кожному пацієнту ми проводили ортопедичне лікування та подальше клінічне спостереження, досліджуючи їх стан після фіксації тимчасових мостоподібних протезів через 1 тиждень та через 1, 3, 6 місяців.

Висновки. За результатами дослідження виявлено високу ефективність визначення ступеня зниження висоти прикусу при підготовці пацієнтів до постійного ортопедичного лікування у залежності від важкості розвитку патологічного процесу.

Ключові слова: висота прикусу, стертість
УДК 616.314-07+616.314-085+616.314.25/.26

\section{ОСОБЕННОСТИ ДИАГНОСТИКИ И ЛЕЧЕНИЯ \\ ПАЦИЕНТОВ СО С НИЖЕНИЕМ ВЫСОТЫ ПРИКУСА}

\author{
А.Б. Костишин \\ Ивано-Франковский нацииональный медицинский \\ университет, кафедра ортопедической \\ стоматологии, \\ 2. Ивано-Франковск, Украина, \\ ORCID ID: 0000-0001-5500-0874, \\ e-mail: kostushunzorjana1907@gmail.com
}

Резюме. Эстетические требования пациентов со снижением высоты прикуса вызывают необходимость применения ортопедических конструкций. Основная причина данного заболевания - патологическое стирание твердых тканей зубов, распространенность которого от $57 \%$ до $91 \%$ и сопровождается нарушениями зубочелюстной системы.

Цель. Исследовать особенности диагностики стоматологического статуса у пациентов со снижением высоты прикуса и сроки его лечения.

Материалы и методы. Определить степень снижения высоты прикуса у лиц с патологическим стиранием твердых тканей зубов и особенности ее восстановления.

Результаты. С целью подготовки к ортопедическому лечению нами было проведено определение высоты прикуса в 123 пациентов. Группу 1 составили 32 человека с включенными дефектами зубных рядов со снижением высоты прикуса до 2 мм, аналогично 2 группу - 31 обследуемый со снижением высоты прикуса 2-4 мм. Соответственно 3 группа - это 30 пациентов со снижением высоты прикуса 4-6 мм. Все обследуемые основных групп, в возрасте 35-55 лет, нуждались в ортопедическом лечении несъемными конструкциями зубных протезов.

Контрольная группа - это 30 молодых людей, в возрасте - 18-34 года, с интактными зубными рядами, без сопутствующей соматической и стоматологической патологии.

Каждому пациенту мы проводили ортопедическое лечение и клиническое наблюдение, исследуя их состояние после фиксации временных мостовидных протезов через 1 неделю и через 1, 3, 6 месяцев.

Выводы. По результатам исследования выявлено высокую эффективность определения степени снижения высоты прикуса при подготовке пациентов к постоянному ортопедическому лечению в зависимости от тяжести развития патологического процесса.

Ключевые слова: высота прикуса, стираемость зубов. зубів.

Стаття надійшла в редакцію 24.12.2020 р. 